коренных малочисленных народов Севера, где уделяется большое внимание эвенкийским играм («Маут на хорей», «Ловля хариуса», «Орор-ахилкан (Олени и волки)»), разработан модуль «Преподавание родного языка» (для педагогов, работающих с детьми-билингвами).

Таким образом, данные направления показывают основные направления научнометодического сопровождения этнокультурного образования в области сохранения эвенкийского языка, позволяют говорить о сформированных инновационных механизмах межведомственного взаимодействия в регионе в области создания единой безбарьерной этнообразовательной среды и можно констатировать, что в Амурской области в части повышения доступа к образовательным услугам представителей коренных малочисленных народов Крайнего Севера создана благоприятная культурнообразовательная среда в рамках реализации «Концепции устойчивого развития коренных малочисленных народов Севера, Сибири и Дальнего Востока Российской Федерации на территории Амурской области».

$$
* * *
$$

1. Закон Амурской области «О гарантиях прав коренных малочисленных народов в Амурской области» от 29.04.2003 №208-оз.

2. Постановление Правительства Амурской области «Об утверждении государственной программы «Развитие и сохранение культуры и искусства Амурской области на 2014 - 2025 годы» от 25.09.2013 № 443 .

3. План мероприятий по реализации в 2016 - 2025 годах Концепции устойчивого развития коренных малочисленных народов Севера, Сибири и Дальнего Востока Российской Федерации на территории Амурской области от 26.12.2016 №162-р.

4. Вакуленко О.Б., Казакова Е.В. Повышение доступа к образовательным услугам коренным малочисленным народам на территории Амурской области//Образование и педагогические науки в XXI веке: актуальные вопросы, достижения и инновации: сборник статей III Международной научно-практической конференции. - Пенза: МЦНС «Наука и Просвещение». - 2018. - С.34-36

\title{
Гаврикова И.Ю. \\ Особенности использования учебных презентаций на занятиях по русскому языку как иностранному
}

Московский физико-технический институт (наџиональньій исследовательский университет) (Россия, Москва)

doi: $10.18411 / s r-10-06-2021-41$

Жизнь современного человека стремительно меняется, эти изменения касаются всех сфер его жизни, включая и сферу образования. Новейшие технологии стали неотъемлемой частью нашей жизни. Так, в частности, одной из основных особенностей современной методики преподавания русского языка как иностранного является возрастающая актуальность использования различных информационнокоммуникативных технологий, а также использование электронных ресурсов в процессе обучения языку.

В числе основных черт современного образования можно назвать следующие: открытость, доступность, интерактивность, ориентированность на развитие коммуникативных навыков, индивидуальный подход к обучению. Использование на занятиях новейших информационно-коммуникативных технологий позволяет в большей степени соответствовать требованиям, предъявляемым к учебному процессу в наше время, а также не противоречить современному стандарту образования.

Всё большую популярность приобретает дистанционная форма обучения, предполагающая использование в процессе обучения различных информационных технологий. Ведущие институты и университеты мира всё более активно внедряют 
элементы дистанционного образования наряду с традиционными формами обучения. В большей степени это продиктовано необходимостью адаптировать современный учебный процесс и учебные материалы к меняющимся условиям современной жизни, в особенности это стало очевидным в 2020-2021 учебном году, ознаменованном ситуацией, связанной с распространением коронавирусной инфекции во всём мире. Сложившаяся непростая для каждой страны ситуация практически не оставила выбора перед руководством многих учебных заведений: подавляющее большинство школ, институтов, университетов, колледжей и других учебных заведений были вынуждены в определенный период времени осуществлять образовательный процесс исключительно с применением дистанционных технологий. В результате этого большому количеству преподавателей пришлось переходить в экстренном порядке на дистанционный формат обучения и адаптироваться к новым условиям, меняя традиционный формат обучения на дистанционный, что повлекло за собой необходимость использования различных информационных технологий при организации и проведении занятий.

Так, для проведения вебинаров использовались различное программное обеспечение (Zoom, Skype, Discord и т.д.), активно использовались образовательные платформы, обучающие программы, а также, безусловно, и разработанные самими преподавателями учебные материалы, в числе которых презентации, созданные на базе программы Microsoft PowerPoint.

В данной статье рассматриваются преимущества и недостатки использования презентаций на занятиях по русскому языку как иностранному в качестве вспомогательного средства и источника дополнительной информации в процессе обучения, наряду с традиционными средствами.

О преимуществах использования различных информационно-коммуникативных технологий, а именно о плюсах использования учебных презентаций, созданных на базе вышеназванной программы, писали многие исследователи, таким образом, использование учебных презентациях на занятиях по русскому языку как иностранному не является чем-то кардинально новым. Однако в последнее время можно говорить о том, что учебные презентации стали неотьемлемой частью образовательного процесса в меняющихся условиях образовательной среды, в связи с чем целесообразно рассмотреть достоинства, недостатки использований презентаций на занятии, а также возможные пути их устранения более детально.

Кратко перечислим основные преимущества организации учебного материала в виде презентации: наглядность, иллюстративность, схематичность (т.е. возможность представления материала в виде таблиц и схем), информативность, интерактивность (возможность добавления интерактивных элементов, тестов и т.д.), доступность (учащийся может просмотреть презентацию бесконечное число раз в любое удобное для него время), возможность создания учебных материалов любого объема в зависимости от целей и задач конкретного этапа процесса обучения.

Сочетание всех вышеперечисленных особенностей представления материала в виде учебной презентации позволяет в существенной степени повысить мотивацию учащихся к процессу обучения. Примечательно то, что использовать учебные презентации на занятиях по русскому языку как иностранному возможно в рамках любой части курса, будь то вводно-фонетический или корректирующий фонетический курс; курс, ориентированный на представление грамматического материала; лексический курс; лингвокультурологический курс, целью которого является познакомить иностранных учащихся с русской культурой и реалиями жизни в России, отражёнными в языке и т.п.

Следует отметить ряд преимуществ использования презентации на занятиях по русскому языку для каждого из вышеперечисленных типов курса. Итак, в рамках фонетического курса представляется возможным использовать учебные презентации, содержащий информацию о фонетической системе русского языка, звуках русского 
языка. В структуру учебной презентации можно включать различные медиафайлы, в частности образцы произношения звуков, сочетаний звуков и слов, содержащих изучаемый звук. Работая с учебной презентацией, учащийся может просматривать её несколько раз, а также воспроизводить звук по желанию неоднократно, что позволит развить и закрепить артикуляционные навыки. Безусловно, если речь идет о фонетическом курсе, нельзя не отметить тот факт, что при введении новой фонетической единицы можно не только продемонстрировать её транскрипцию, образец произношения, слова, её содержащие, но и различные схемы, иллюстрирующие положение органов речи (языка, губ) в момент произнесения данного звука, что особенно актуально при введении некоторых звуков русского языка, отсутствующих в фонетических системах многих других языков (звуки [р], [ы] и др.), что не всегда является возможным в рамках занятия в аудитории, так как далеко не все учебника для начального уровня изучения русского языка как иностранного содержат подобный иллюстративный материал, т.е. преподавателю приходится самостоятельно его искать, тогда как организовать этот материал в формате учебной презентации достаточно удобно.

Что касается лексического курса, то и здесь нельзя не отметить ряд преимуществ использования учебных презентаций. Как уже было сказано ранее, одной из особенностей презентации является её наглядность: здесь стоит упомянуть хотя бы о возможности семантизации новой лексической единицы с помощью иллюстративного материала, что в значительной степени способствует запоминанию данной единицы, так как введение нового слова с использованием какого-либо иллюстративного материала «запускает» ассоциативные механизмы памяти учащегося, таким образом новое слово запоминается быстрее и дольше остаётся в памяти. Такой способ семантизации лексики даёт особенно хорошие результаты, если у учащегося развита зрительная и ассоциативная память.

Если речь идёт о грамматическом материале, то такие особенности учебной презентации, как наглядность и схематичность играют немаловажную роль. Грамматический материал представляется возможным проиллюстрировать различными примерами, сопровождая их фотографиями или графическими изображениями, а в конце или в начале изложении нового грамматического материала можно организовать его в виде таблицы, что позволяет структурировать изученный материал, обобщить его для последующей работы с ним на занятиях.

В рамках лингвокультурологического курса использование презентаций помогает не только вводить новые речевые единицы, выражения, речевые клише, содержащие лингвострановедческий компонент, но и иллюстрировать их с помощью фотографий, динамических изображений и даже коротких видео.

Практически любой новый материал: лексико-грамматический и лингвокультурологический в особенности предпочтительнее демонстрировать на примере живых диалогов, что помогает повысить мотивацию учащихся к процессу обучения, так как создаётся эффект вовлеченности в конкретную речевую ситуацию, присутствует эффект возможности принять в них участие, что так или иначе способствует развитию коммуникативных навыков учащегося, а формирование коммуникативных навыков, как известно, играет одну из важнейших ролей, ему отводится особое место в рамках современного образовательного стандарта.

Презентации на основе PowerPoint можно использовать не только в рамках разного вида курсов на всех этапах обучения русскому языку как иностранному, но и в качестве различных структурных элементов курса. Существует несколько возможных способов использования учебной презентации на занятиях. Например, презентацию можно использовать в начале изучения новой темы, такая презентация должна содержать основную информацию о материале, который будет изучаться в ближайшие 
учебные часы. Считается, что учебная презентация должна предшествовать теме, на изучение которой отводится 6-8 академических часов. После предъявления основной информации в виде схем, таблиц, речевых клише, диалогов и т.д. преподаватель может приступить к объяснению и комментированию материала, представленного в виде презентации.

Презентацию также представляется возможным включить непосредственно в процесс объяснения новой темы для иллюстрирования какого-либо материала. Это позволяет разнообразить учебный процесс за счёт представления иллюстраций по теме, а также живых диалогов или коротких видео, что помогает повысить мотивацию учащихся, а это в конечном счете приводит к росту эффективности учебного процесса.

Учебную презентацию можно использовать в качестве завершающего элемента работы над какой-либо темой, то есть такая презентация служит для структуризации и закрепления изученного материала. Предпочтительно включение в неё схем, таблиц, речевых образцов, коротких диалогов, небольших по объёму текстов. Это позволяет систематизировать изученный материал с целью развития коммуникативных навыков общения с использованием изученного лексического и грамматического материала.

Наконец, презентацию можно использовать в качестве вспомогательного средства обучения, наряду с традиционными, такими как учебник, учебные пособия, рабочие тетради и т.д. Такая презентация может быть предложена учащимся в качестве источника дополнительной информации по изученной теме или в качестве методического материала для повторения и отработки изученного материала. Таким образом, использование презентаций на любом этапе процесса обучения языку имеет свои преимущества.

Одной из особенностей учебной презентации, как было отмечено ранее, является её интерактивность. Интерактивность представляет собой одну из отличительных черт современного образовательного процесса, именно она обуславливает вовлеченность учащегося в процесс изучения нового материала, отработку полученных навыков и умение применять знания на практике в условиях непосредственного речевого общения на изучаемом языке. Именно благодаря этому учащийся превращается из пассивного наблюдателя в активного участника диалога.

Интерактивность презентации достигается несколькими способами. Во-первых, такая презентация может содержать специальный блок заданий из рубрики «проверь себя»: к примеру, учащемуся может быть предложен вопрос, на который следует дать ответ; соотнести части предложения; использовать слова, данные в скобках, в правильной форме; вставить окончания; подобрать подходящие для описания иллюстраций прилагательные; назвать предмет, который они видят на слайде; задать вопрос с соответствующим вопросительным словом и многое другое. В таком случае преподаватель может дать учащимся несколько секунд на обдумывание вопроса, предложив самостоятельно дать на него ответ, а затем дать правильный ответ, прокомментировав то или иное грамматическое явление, представленное на презентации.

Ещё одним способом придания интерактивности презентации является включение небольших тестов, которые появляются в процессе просмотра презентации: так, чтобы продолжить просмотр презентации, учащемуся необходимо дать ответ на поставленный вопрос. В связи с тем, что такое задание представлено в виде теста, оно не отнимает много времени, однако способствует повышению концентрации внимания учащегося, опять же переводя его из роли пассивного наблюдателя в роль активного участника учебного процесса. Учащиеся также получают возможность проверить свои знания, закрепить полученные навыки и продолжить их развивать в процессе дальнейшей работы над данной темой. Тест также можно дать и после просмотра презентации с целью контроля и проверки степени усвоенности учащимся материала в рамках той или иной лексико-грамматической темы. 
Итак, учебную презентацию представляется возможным использовать на занятиях по русскому языку как иностранному различными способами, каждый из которых имеет свои безусловные преимущества. Несмотря на то, что для подготовки материалов и оформления их в виде презентации зачастую преподавателю требуется затратить много времени и сил, включение данного элемента мультимедийных технологий позволяет добиться лучших результатов обучения, в связи с этим можно предположить, что актуальность использования на занятиях по русскому языку различных информационно-коммуникативных технологий, презентаций в частности, со временем будет только возрастать.

$$
* * *
$$

1. Азимов Э.Г. Использование компьютера в обучении русскому языку как иностранному. - М.: Русский язык, 1989. - С. 64-67.

2. Байбурина К.А., Ертаева Н.К., Кокенова З.К. Применение мультимедийных технологий при обучении студентов-иностранцев русскому языку. - Вестник КазНМУ. - Алматы, 2016. - С. 102106.

3. Руденко-Моргун О.И. Компьютерные технологии как новая форма обучения РКИ // Традиции и новации в профессиональной деятельности преподавателя русского языка как иностранного: Учебная монография / Под общей ред. С.А. Хаврониной, Т.М. Балыхиной. - М.: Российский университет дружбы народов, 2002. - С. 87-89.

4. Серова Л.К. Компьютерные технологии на начальном этапе преподавания РКИ // Традиции и новации в профессиональной деятельности преподавателя русского языка как иностранного: Учебная монография / Под общей ред. С.А. Хаврониной, Т.М. Балыхиной. - М.: Российский университет дружбы народов, 2002. - С. 42-43.

5. Трофимова Г.Н., Барышникова Е.Н. Русский язык и интернет: проблемы обучения // Традиции и новации в профессиональной деятельности преподавателя русского языка как иностранного: Учебная монография / Под общей ред. С.А. Хаврониной, Т.М. Балыхиной. - М.: Российский университет дружбы народов, 2002. - С. 54-55.

6. Фадеев С.В. ЭВМ в преподавании русского языка как иностранного. - М.: Рус. яз., 1990. - С. 91.

\section{Ганжа И.С. \\ Диагностика успешности деятельности педагога}

Таганрогский институт имени А.П. Чехова (филиал) ФГБОУ ВПО «Ростовский государственный экономический университет (РИНХ)»

doi: $10.18411 / s r-10-06-2021-42$

(Россия, Таганрог)

\section{Аннотация}

В статье рассматриваются основные особенности понятия успешности. В работе изучено также понятие профессиональная успешность, его сущность. В данной статье описаны основные критерии успешности педагогической деятельности.

Ключевые слова: педагогическая диагностика, успех, успешность.

\section{Abstract}

The article discusses the main features of the concept of success. The paper also examines the concept of professional success, its essence. This article describes the main criteria for the success of pedagogical activity.

Keywords: pedagogical diagnostics, success, success.

В настоящее время проблема оценки качества профессиональной деятельности сотрудников образовательных учреждений становится все более актуальной, поскольку именно руководители образовательных учреждений несут ответственность за создание условий для управления. эффективная профессиональная деятельность учителей. Очевидно, что решение данной проблемы невозможно без разработки инструментария 